ISSN 2078-6441. Вісник Львівського університету. Серія географічна. 2013. Випуск 42. С. 64-77. Visnyk of the Lviv University. Series Geography. 2013. Issue 42. P. 64-77.

$631.445 .12(477.41 / 42)$

\author{
олодимир ськевич, рія ецик \\ ьвівський н ціон льний університет імені в н \\ вул. . орошенк , 41, 79000, м. ввів, кр їн, \\ e-mail: haskevich_vg@ukr.net
}

$\mathrm{x}$ р ктеризов но генетико-геогр фічні особливості торфових грунтів лого олісся. результ т ми польових і л бор торних досліджень висвітлено геогр фію торфових грунтів, про н лізов но їхню морфологічну будову, фізичні т фізико-хімічні вл стивості. озглянуто суч сний гроекологічний ст н торфових грунтів, з ходи їхнього р ціон льного використ ння й охорони.

лючові слов : торфові грунти, торфовищ, геогр фія торфових грунтів, морфологічні озн ки, осушення, дегр д ція, охорон грунтів.

олот і торфовищ - невіддільний трибут м лополіських л ндш фтів. они поширені по всій території досліджень і н д ють лому оліссю специфічного поліського колориту, є однією 3 х р ктерних природних рис, що визн ч ють його як “своєрідну фізико-геогр фічну обл сть” [9, с. 138]. . руск вецький з зн ч є, що людин від поч тку господ рчої діяльності н м Г л сь оп нув ти т ємницями боліт і їхніми прихов ними можливостями для з безпечення своїх життєвих потреб. юди з д вніх-д вен використовують болотні м сиви для з готівлі ягід, грибів, лік рських рослин, Як місця для полюв ння [8, с. 9].

кож болот зн чно вплинули н х р ктер поселень лого олісся, ст н земельних ресурсів і сільськогоспод рське використ ння території. риродні з болочені сінож ті й п совищ сприяли розвитку тв ринництв , великі покл ди торфу використовув ли як п ливо, т кож орг нічне добриво для порівняно низькородючих поліських грунтів [1, с. 49].

структурі грунтового покриву болотні й торфові грунти лого олісся посід ють в гоме місце. х м йже повністю осушено, використовують перев жно як низькопродуктивні сінож ті, п совищ, інколи під ріллею. г то осушених торфовищ $\epsilon$ 3 кинутими, з росли ч г рник ми т бур'ян ми, не вл стивими рослинним угрупов нням природних болотних екосистем.

олот як унік льні природні екосистеми є регулятор ми водного, гідрогеохімічного, мікроклім тичного й с ніт рного режимів територій їхнього поширення, місцем перебув ння і гніздув ння болотної дичини й перелітних пт хів, об'єкт ми мисливських угідь, рекре ційними зон ми. мість того, щоб ув ж ти болотні землі спільником у н м г нні не лише збільшити сировинну і продовольчу б зу, й зберегти здорове довкілля, буферну зд тність екосистем і генофонд, людин оголосил цим землям еког небну боротьбу і проводить безпідст вний широком сшт бний н ступ [8, с. 5-6].

(C) ськевич ., ецик ., 2013 
орфові грунти є н дто вр зливими до зовнішніх, не декв тних нтропогенних впливів. е зумовлено їхньою низькою буферністю до різких змін вл стивих їм природних режимів, особливостями речовинного скл ду і вл стивостями, генезисом т умов ми з ляг ння в рельєфі, т кож тими к рдин льними змін ми, яких грунти з зн ють після осушув льних меліор цій і н ступного використ ння під сільськогоспод рські угіддя, н с мперед ріллю.

меж $\mathrm{x}$ лого олісся торфові грунти вивчені недост тньо, н с мперед їхня геогр фія, генез, особливості структури грунтового покриву, т кож суч сний грунтово-меліор тивний т гроекологічний ст н. они з зн ли нег тивних процесів нтропогенного х р ктеру, т ких як мех нічне спр цюв ння, прискорен мінер ліз ція орг ніки, дефляція, пірогенн дегр д ція тощо $[1,2]$. одноч с, відповідно до ст тті 150 емельного кодексу кр їни (2001), “торфовищ з глибиною з ляг ння торфу більше 1 м і осушені нез лежно від глибини...” н леж ть до к тегорії особливо цінних земель, отже, потребують особливої охорони й р ціон льного використ ння [3, с. 53]. ому дослідження торфових грунтів лого олісся, їхнього суч сного ст ну, розробк 3 ходів рен тур ліз ції й охорони $є$ кту льним, м $є$ н укове і прикл дне зн чення.

ст нніми десятиліттями в кр їні вийшло м ло н укових пр ць, присвячених болотним й торфовим грунт м. дебільшого у н укових публік ціях використовув ли д ні великом сшт бних обстежень грунтів 1958-1961 років бо результ ти їхнього коригув ння. ому з слуговує н ув гу моногр фія . руск вецького “ орфові грунти і торфовищ кр їни” [8]. н уковій пр ці втор сх р ктеризув в умови гідроморфного грунтоутворення н території кр їн, морфолого-генетичні особливості торфовищ, фізичні, хімічні й біологічні вл стивості торфових грунтів. исвітлено т кож суч сний гроекологічний ст н осушув них торфових грунтів, їхню роль і функції в екосистем х [8].

езульт ти досліджень меліор тивного ст ну торфових грунтів і торфовищ лого олісся н ведено у публік ціях . ознюк, . озловського, . урд н т ін. роблеми пірогенної дегр д ції торфових грунтів лого олісся, зміни вл стивостей грунтів і рослинного покриву в процесі пірогенезу розглянуто у пр цях . ськевич , ецик (2007, 2008, 2010, 2011).

ході дослідження торфових грунтів лого олісся ст вили т кі з вд ння: вивчити генезу т структуру грунтового покриву торфових грунтів, про н лізув ти морфологію т вл стивості, сх р ктеризув ти гроекологічний ст н торфових грунтів і торфовищ. б’єктом досліджень є торфові грунти і торфовищ лого олісся. редмет дослідження - генезис, грунтові комбін ції, морфологічні особливості будови профілю, фізичні і фізико-хімічні вл стивості грунтів.

орфові грунти вивч ли н ст ціон рних і н півст ціон рних дослідних ділянк х у меж х фізико-геогр фічної обл сті лого олісся - н території леської селищної р ди уського р-ну, ублянської міської р ди овківського р-ну (долин ричівського потоку), тоянівської селищної р ди дехівського р-ну, орчівської т ужелянської сільських р д ок льського р-ну (долин р. олокія) ьвівської обл. ілянки з кл д ли у вигляді к тен н різних вид $\mathrm{x}$ торфових грунтів. р ховув ли т кож пірогенну дегр д цію торфових грунтів. дослідженнях ч стково використ но фондові м тері ли к федри грунтозн вств і геогр фії грунтів ьвівського н ціон льного університету імені в н p нк, літер турні джерел . н літичні роботи викон но в л бор торії н лізу грунтів к федри грунтозн вств і геогр фії грунтів. 
ля дослідження торфових грунтів використовув ли т кі методи: порівняльногеогр фічний, порівняльно-профільний, грунтових к тен, н літичний, ст тистичний.

ізико-геогр фічні умови лого олісся, с ме-рівнинний рельєф, що породжує сл бку дренов ність території, н явність сл бкостічних з п динних ділянок і широких з болочених з пл в річок, плоских міжп смових долин, сприяють формув нню i зн чному поширенню болотних і торфових грунтів. лощ болотних, торфув тоболотних, торфово-болотних грунтів й торфовищ ст новить 1 293,48 км², бо 15,44\% від 3 г льної площі території досліджень [2]. йбільші м сиви торфових грунтів зосереджені в тинському, усько- родівському, дехівському, кво- ілійському природних р йон х лого олісся, менше - н смовому обужжі, ідподільському т епетівському природних р йон х.

ідроморфний ряд грунтів поділяють н дві великі н дтипові групи: гідроморфні мінер льні т гідроморфні орг ногенні. декільк пропозицій щодо норм тиву вмісту орг нічної м си для поділу гідроморфних грунтів н мінер льні й орг ногенні. . еред пороговим зн ченням поділу гідроморфних грунтів н мінер льні й орг ногенні пропонув в ув ж ти н рівні $15 \%$ вмісту орг нічної м си. . руск вецький рекомендув в узяти 3 т кий пороговий норм тив $20 \%$ [8, с. 156].

орфовий грунт, згідно з визн ченням . криннікової, це верхній ш р торфу н глибину поширення основної м си коренів рослин, який періодично з зн є ер ції і де відбув ються процеси розкл ду рослинних відкл дів т утворення високомолекулярних орг нічних речовин. ижчі ш ри торфу не можн н зив ти грунтом, оскільки грунтотворні процеси тут не простежуються, с м торф перебув є в 3 консервов ному ст ні. ей ш р н зв ний орг ногенною породою [4].

енез т розвиток торфових грунтів пов'яз ні з кумуляцією орг ногенної речовини в умов х н длишкового зволоження т обмеженого доступу ксигену, шо спричиняє сповільнений розкл д рослинних решток. они формуються вн слідок 3 рост ння водойм бо з болочув ння суходолів.

орфові грунти н території лого олісся 3 генезою і розвитком пов'яз ні з долин ми стоку льодовикових вод, д вніх і суч сних річок. Звич й вони розт шов ні в з пл в х м лих річок і перших н дз пл вних тер с х великих річок. сновним джерелом водного живлення іх є річкові води, зб г чені мінер льними ч стин ми т орг нічними речовин ми. цьому р зі в жливе зн чення, особливо н пізніших ет п х розвитку боліт, м ють грунтові води, т кож поверхнево-стічні води з умов більш вироблених долин т з посиленням вологості клім ту, коли виявляється і деякий вплив тмосферних оп дів. ке положення в рельєфі $є$ причиною розвитку тут м йже винятково евтрофних боліт.

еоморфологічно більшість м сивів болотних і торфових грунтів зосереджен головно в широких долин х приток першого і другого порядків хідного угу ( олокії, олотні, ілого току, ричівського потоку, умниці), тиру ( удилівки, стрівки, лонівки, ерезівки, дост вки, олдурівки, ляшівки, мишівки) і орині (рік ілія т пї притоки витеньки). зв ні притоки м ють широтне бо субширотне простяг ння, їхні долини м йже повністю бо ч стково з болочені. формов ні тут торфовищ н леж ть до долинного типу. $з$ пл ві хідного угу торфових грунтів i торфовищ дуже м ло. долин х тиру, кви, ти торфовищ 3 йм ють ч стину з пл ви, утворюючи грунтові комплекси 3 іншими грунт ми. кі торфовищ не $є$ постійно з топленими, їх з лив ють річкові води в ч с повеней і п водків [7]. 
рім м сивів торфових грунтів, розміщених у долин х великих, середніх і м лих м лополіських річок, 6 г то невеликих 3 площею боліт і торфовищ розт шов но в долин х дрібних річок і потічків, долиноподібних зниженнях реліктових річок, сл бкостічних і безстічних $з$ п дин х [7].

території кр їни, i лого олісся зокрем, торфові грунти н леж ть до інтр зон льних. роте, . руск вецький не р дить з числяти гідроморфні грунти цілком до інтр зон льних, оскільки в осушув них гідроморфних грунт х з ч сом щор з чіткіше виявляються озн ки зон льності [8, с. 153].

еогр фія торфових грунтів лого олісся визн чен природними умов ми території, зокрем , х р ктером рельєфу, мікрорельєфу, особливостями річкової мережі. олотні й торфув то-болотні (Gleysols Histic (GLhi), Fluvisols Histic (FLhi), WRB, 1998) грунти з йм ють площу 652,70 км², що ст новить 7,79\% від території лого олісся [2]. йбільші м сиви торфув то-болотних грунтів поширені в долин х рік удилівК (лів приток р. тир), рт цьк і мишівк (пр ві притоки р. кв ), у долині p. кв , у долині р. ричівк, в околицях смт лесько. евеликі з площею м сиви торфув то-болотних грунтів зустріч ються в епетівському природному р йоні [5].

орфово-болотні грунти і торфовищ низинні (Histosols Sapric (HSsa), Histosols Salic (HSsz), Histosols Folic (HSfo)) з йм ють площу 640,78 км², бо 7,65 \% від території досліджень [2]. еликі м сиви торфово-болотних грунтів поширені в долин х м лополіських річок т, едільчин, ричівк, стрівк, дост вк, лонівк , овдурівк, тир т інших, т кож в околицях м. оснівк , смт лесько, сіл юбеля, оянець овківського р-ну, опорів і блунівк уського р-ну, струбичі дехівського р-ну, ривичі олочівського р-ну ьвівської обл.; рупець дивилівського р-ну івненської обл. лям ми різної площі торфово-болотні грунти тр пляються в епетівському природному р йоні [5].

торфових грунтів н лому оліссі н йч стіше фіксують торфовищ низинні різної потужності - від неглибоких до н дглибоких. йбільші 3 площею м сиви торфовищ низинних зосереджені в долин х річок олокія, удилівк , ілостік, стрівк , тир, овдурівк, кв , ричівк, лонівк, ляшівк, мишівк т ін. н чні м сиви торфовищ низинних приурочені до депресій рельєфу і долин невеликих потоків, зокрем , в околицях смт лесько, сіл уровичі і ривичі олочівського р-ну, с. митрів дехівського р-ну ьвівської обл., с. овом лин строзького р-ну т ін. кож торфовищ низинні контур ми різної площі поширені в долин х річок т , олотня, ерезівк, руньк, едільчин, умниця т ін. орфовищ низинні лого олісся м ють зн чну потужність, досяг ючи 8-11 м у долин х рік олокія, удилівк , Кв , мишівк .

рбон тні торфовищ низинні тр пляються в околицях н селених пунктів лесько уського р-ну, оп тин дехівського р-ну, т нісл вчик родівського р-ну, ідилів м'янк - узького р-ну, уровичі олочівського р-ну ьвівської обл., ерб убенського р-ну івненської обл. [5].

труктур грунтового покриву боліт і торфових грунтів лого олісся скл дН і недост тньо досліджен . орфові грунти простежуються як однорідними контур ми, т к i, здебільшого, утворюють грунтові комбін ції з іншими грунт ми. грунтових комбін цій у структурі грунтового покриву н йпоширенішими є плямистості, які утворюють між собою торфовищ низинні різної потужності, що спричинено особливостями рельєфу мінер льного дн боліт. кож плямистості утворюють нек рбон тні і к рбон тні торфовищ, недегр дов ні і пірогенно дегр дов ні, з різним ступенем 
розкл ду орг ніки, мінер ліз ції, з н явністю чи відсутністю мінер льних н носів н поверхні (мод льні й похов ні торфовищ низинні).

шети утворюють торфув то-болотні й торфово-болотні грунти. они поширені перев жно по периферіях великих боліт, у меж х депресій рельєфу.

кл днішими і контр стнішими грунтовими комбін ціями є поєдн ння. лому оліссі н йч стіше тр пляються поєдн ння болотних грунтів з торфув то-болотними, болотних грунтів з торфово-болотними і торфовищ ми низинними неглибокими, лучних к рбон тних і дернових к рбон тних глейових грунтів з торфовищ ми низинними, дернових глейових грунтів з торфово-болотними і торфовищ ми низинними, торфово-болотними і торфув то-болотними з болотними грунт ми, торфовищ ми низинними з лучними і дерновими глейовими грунт ми, торфув то-болотних і торфово-болотних грунтів з торфовищ ми низинними, торфовищ низинних 3 торфув тоболотними і торфово-болотними грунт ми, торфовищ низинних к рбон тних з торфово-болотними грунт ми.

рослинному покриві торфовищ лого олісся перев ж ють очеретяні, осокові й осоково-гіпнові угрупов ння, у тому числі схенусово-гіпнові. рідк $є$ вільшняки i березняки. ому 3 бот нічним скл дом н йбільше поширені очеретяні торфи, менше - очеретяно-осокові, осокові, осоково-гіпнові. ступенем розкл ду орг ніки перев ж ють сл бко т середньо розкл дені торфовищ . верхньому ш рі торфові грунти сильно розкл дені, ч сто сильно мінер лізов ні, зокрем , осушені грунти, які використовув ли під ріллею.

території лого олісся поширені болотні мінер льні й торфові грунти низинного типу. олотні мінер льні грунти не м ють орг ногеної товщі. потужністю торфу орг ногенні грунти поділяють н торфув то-болотні (до 20 см), торфово-болотні (20-50 см), торфовищ неглибокі (50-100 см), середньоглибокі (100-200 см), глибокі (200-400 см) і н дглибокі (пон д 400 см) [6]. отужність торфу з лежить від особливостей морфології мінер льного дн болот т віку торфовищ. ксим льн потужність торфовищ лого олісся ст новить 11 м [7].

ля х р ктеристики будови профілю торфув то-болотних к рбон тних грунтів н ведемо опис розрізу 194, з кл деного н північний схід від смт лесько уського р-ну ьвівської обл.

гіддя - рілля. ультур - ріп к (стерня).

кип ння від $10 \% \quad-3$ поверхні.

либин 3 ляг ння грунтових вод - не виявлено.

кор. - торфово-гумусовий горизонт, темно-сірого 36 рвлення 3 коричневим 0-17 см відтінком, 10YR3/1 з шк лою нселл, неоднорідний, грудкув тодрібнозернистої структури, сухий, сл бкоущільнений, тріщинув тий, тр пляються приор ні кусочки мергелю, кв рцовий пісок, к рбон тний, рештки мушель молюсків, червоточини, корінці рослин, перехід до горизонту gl ясний $з$ з б рвленням, язикув тий, 3 тічний, збіг ється з глибиною ор нки;

$\mathrm{Kgl} \mathrm{-} \mathrm{гумусовий} \mathrm{перехідний} \mathrm{горизонт,} \mathrm{темнув} \mathrm{то-сірого} 36$ рвлення 17-23 см $\quad 3$ бурув то-сірим відтінком, 10YR6/1, дуже неоднорідний, легкоглинистий, грудкув то-брилистий, вологий, дуже щільний, тріщинув тий, к рбон тний, скупчення к рбон тів у формі прожилок, корінці рослин, кореневини, перехід до горизонту hgl поступовий з з б рвленням; 
hкgl - перехідний сл бкогумусов ний горизонт, сірув то-білястого з 6 рвлення

23-42 см 3 жовтими плям ми, 10YR8/3, неоднорідний, легкоглинистий, брилув тої структури, сирий, дуже щільний, тріщинув тий, к рбон тний, вохристі плями ді метром від 2-3 до 5-7 см, зрідк корінці рослин, кореневини, кусочки н піввивітреного мергелю, перехід до горизонту (h)kGl поступовий з з б рвленням;

(h)KGl - перехідний горизонт, дуже сл бкогумусов ний, білясто-сірого з 6 рвлен42-48 cм ня, 10YR8/2, неоднорідний, легкоглинистий, безструктурний, сирий, дуже щільний, в'язкий, к рбон тний, тріщинув тий, вохристі плями ді метром 7-10 см, 3 клинки гумусов ного дрібнозему по тріщин $\mathrm{x}$, перехід до горизонту $\mathrm{kGl}$ поступовий з з 6 рвленням;

KGl - елювій мергелів, вохристого з сірув то-білястим відтінком 36 рвлення, $48-60 \mathrm{~cm}$ 10YR8/1, неоднорідний, безструктурний, легко-глинистий, сирий, дуже щільний, в'язкий, к рбон тний, вохристі плями ді метром 10-15 см.

орфув то-болотні грунти лого олісся вирізняються незн чним з потужністю торфовим горизонтом, який ун слідок трив лого осушення т використ ння під ріллею, м є дуже високий ступінь розкл ду, сильно мінер лізов ний і м йже повністю втр тив озн ки торфу.

ля х р ктеристики будови профілю торфово-болотних к рбон тних грунтів н ведемо опис розріз 193, з кл деного н північний схід від смт лесько уського р-ну ьвівської обл.

гіддя - переліг. ослинність - зл кове різнотр в’я, осот, у мікроз п дин х - осок , очерет.

кип ння від $10 \% \quad-3$ поверхні.

либин з ляг ння грунтових вод - не виявлено.

$\begin{array}{cl}\text { Hd } & - \text { дернин ; } \\ 0-5 \text { см } & \text { торфовий горизонт, сильно мінер лізов ний, темно-сірого з коричнюв - } \\ \text { кор. } & \text { тим відтінком } 3 \text { бвлення, 10YR2/1, неоднорідний, дрібногрудкув то- } \\ 5-28 \text { см } & \text { зернистої структури, свіжий, ущільнений, тріщинув тий, к рбон тний, } \\ & \text { переплетений корінцями рослин, містить зерн кв рцу, червоточини, } \\ & \text { перехід до горизонту ясний } 3 \text { з бвленням, збіг ється з глибиною }\end{array}$ колишньої ор нки;

hк - торфово-гумусовий горизонт, середньомінер лізов ний, темно-

28-39 см коричневого з б рвлення, 10YR $2 / 2$, неоднорідний, грудкув то-зернистої структури, вологий, сл бкоущільнений, тріщинув тий, к рбон тний, тр пляються рештки н піврозкл деної деревини, трухляві кореневини, корінці рослин, перехід до горизонту $\mathrm{hkgl}$ ясний з з б рвленням;

hkgl - перехідний сл бкогумусов ний горизонт, сірув то-білястого з 6 рвлення, 39-45 см 10YR7/2, неоднорідний, легкоглинистий, безструктурний, сирий, щільний, в'язкий, тріщинув тий, к рбон тний, зрідк корінці рослин, кореневини, по кореневин х ірж во-вохристі з тіки, червоточини, перехід до (h)кGl ясний, язикув тий з з б рвленням;

(h)кGl - перехідний горизонт, дуже сл бкогумусов ний, білястий з вохристими i 45-63 см сірими плям ми, 10YR8/2, неоднорідний, легкоглинистий з домішк ми фр кції крупного піску, безструктурний, дуже щільний, сирий, в'язкий, тріщинув тий, кореневини, вохристі плями ді метром 3-5 см, з лізистом нг нові пункт ції, кут ни довкол кореневин, перехід до горизонту кGl поступовий з з б рвленням, язикув тий, з тічний; 


\footnotetext{
KGl - елювій верхньокрейдових мергелів, білясто-сірого кольору, 10YR8/1, 63-80 см неоднорідний, безструктурний, легкоглинистий, сирий, дуже щільний, тріщинув тий, вохристі плями оглеєння.
}

орфово-болотні грунти, н відміну від торфув то-болотних, більше поширені н території лого олісся, м ють потужніший орг ногенний горизонт, який у верхній ч стині профілю сильно мінер лізов ний т розкл дений.

ля х р ктеристики будови профілю торфовищ неглибоких к рбон тних н ведемо опис розрізу 195, з кл деного н північний схід від смт лесько уського р-ну ьвівської обл.

гіддя - переліг. ослинність - зл кове різнотр в'я, осот, в пониженнях - осок , очерет. р пляються кущі верби, вільхи, глоду.

кип ння від $10 \% \quad-3$ поверхні.

либин $з$ ляг ння грунтових вод - не виявлено.

Hd - оторфов н дернин (очіс);

$0-8 \mathrm{~cm}$

Тhкор. - торфовий горизонт, сильно розкл дений, коричнево-темно-сірого

8-20 см 36 рвлення, 10YR3/1, грудкув то-зернистий, розсипч стий, пухкий, сухий, к рбон тний, переплетений корінцями рослин, червоточини, дрібні мушлі молюсків, перехід до горизонту к ясний 3 з б рвленням, збіг ється з глибиною колишньої ор нки;

к - торфовий горизонт, середньорозкл дений, коричнево-бурий, $10 \mathrm{YR} 3 / 2$,

20-52 см вологий, тріщинув тий, губч стий, к рбон тний, червоточини, корінці рослин, кореневини, тр пляються н піврозкл дені рештки рослин, перехід до горизонту к ясний з з б рвленням;

к - перехідний горизонт, добре гумусов ний, сірув то-вохристого $з 6$ рвлен-

52-56 см ня, 10YR6/2, неоднорідний, грудкув то-брилув тої структури, легкоглинистий, сирий, в'язкий, липкий, к рбон тний, оглеєння у формі вохристих плям і з лізисто-м нг нових пункт цій, зрідк корінці рослин, кореневини, червоточини, перехід до горизонту $\mathrm{hkgl}$ ясний з з 6 рвленням, язикув то3 тічний;

hkgl - перехідний горизонт, дуже сл бкогумусов н грунтотворн пород, 56-64 см білясто-вохристого з б рвлення, 10YR7/1, легкоглинистий, безструктурний, сирий, дуже щільний, в'язкий, тріщинув тий, к рбон тний, з клинки гумусов ного дрібнозему по тріщин х, тр пляються червоточини, корінці рослин, кореневини, перехід до горизонту кGl поступовий з з 6 рвленням, язикув тий;

kGl - грунтотворн пород, елювій мергелів, білястого 3 вохристими плям ми 64-90 см 3 б рвлення, 10YR8/1, легкоглинистий, безструктурний, сирий, дуже щільний, оглеєння у формі вохристих плям.

ля х р ктеристики будови профілю торфовищ низинних середньоглибоких н ведемо опис розрізу 198, з кл деного н південний схід від с. т ївк ок льського р-ну ьвівської обл., в долині р. олокія. норельєф у формі купин.

гіддя - п совище. ослинність - осок , ситник, зл кове різнотр в'я.

кип ння від $10 \% \quad-$ нем є.

либин $з$ ляг ння грунтових вод $-131 \mathrm{~cm}$. 
Hd - дернин ;

$0-3 \mathrm{~cm}$

$\mathrm{T}_{1} \mathrm{~h}$

$3-17 \mathrm{~cm}$

- торфовий горизонт, дуже добре розкл дений, сильно мінер лізов ний, темно-сірий з коричневим відтінком, 10YR2/1, неоднорідний, зернистої структури, сирий, сл бкоущільнений, тр пляються піщинки кв рцу, переплетений корінцями рослин, червоточини, перехід до горизонту $\mathrm{T}_{2 \mathrm{Fe}}(\mathrm{K})$ різкий 3 з б рвленням, язикув то-хвилястий;

$\mathrm{T}_{2 \mathrm{Fe}} \quad-$ торфовий горизонт, сильнорозкл дений, коричневого 36 рвлення 3

17-31 см ірж вим відтінком, 10YR2/2, неоднорідний, дрібнозернистої структури, н зл м х н тіки оксидів з ліз, сирий, містить піщинки кв рцу, корінці рослин, перехід до горизонту 3 (к) ясний з з б рвленням;

$31-72^{3} \mathrm{~cm}$ - торфовий горизонт, середньорозкл дений, коричневого з 6 рвлення, 10YR2/2, мокрий, пухкий, губч стий, містить рештки н піврозкл дених болотних рослин, корінці рослин, перехід до горизонту 4 ясний 3 з б рвленням;

$\mathrm{T}_{4}-$ торфовий горизонт, сильнорозкл дений, темно-сірий 3 коричневим 72-93 см відтінком, 10YR2/1, можн розім'яти в однорідну м су, мокрий, пухкий, зрідк тр пляється крупний пісок, містить н піврозкл дені рештки болотних рослин, перехід до горизонту 5 поступовий 3 з 6 рвленням;

$\mathrm{T}_{5}-$ торфовий горизонт, сильнорозкл дений, коричневого 36 рвлення, 93-130 см 10YR2/2, можн розім'яти до однорідної м си, мокрий, пухкий, перехід до горизонту $\mathrm{T}_{6}$ ясний з з 6 рвленням;

$\mathrm{T}_{6}-$ торфовий горизонт, сл бкорозкл дений, світло-коричневого з б рвлення,

130-140 см 10YR4/2, губч стий, мокрий, пухкий, губч стий, перехід до горизонту різкий з з б рвленням;

- перехідний до мінер льної породи горизонт, брудно-сірого з б рвлення,

140-150 см неоднорідний, прош рки піску з торфом, його з лив є водою.

ля х р ктеристики будови профілю торфовищ низинних глибоких н ведемо опис розрізу 189, з кл деного н північний схід від м. убляни овківсьського р-ну ьвівської обл., у долині ричівського потоку. норельєф у формі колишніх борозен від ор нки. вільхи.

гіддя - переліг. ослинність - зл кове різнотр в'я, осок , кропив , кущі верби,

кип ння від $10 \% \quad-$ нем є.

либин 3 ляг ння грунтових вод -124 см.

Thd - торфовий горизонт, сильнорозкл дений, сл бкомінер лізов ний, сильно

0-10 см 3 дернов ний, темно-сірого з б рвлення з бурув тим відтінком, 10YR2/1, дрібнозернистої структури, сухий, пухкий, містить піщинки кв рцу, переплетений корінцями рослин, перехід до горизонту 1 ясний з скл денням;

1 - торфовий горизонт, добре розкл дений, темно-сірий з бурим відтінком, 10YR2/1, дрібнозернистий, вологий, сл бкоущільнений, злегк губч стий, корінці рослин, кореневини, ч стинки кв рцу, червоточини, перехід до горизонту 2 різкий з з б рвленням і скл денням, збіг ється з глибиною колишньої ор нки; $\begin{array}{cl}2 & - \text { торфовий горизонт, середньорозкл дений, темно-бурого з } 6 \text { рвлення, } \\ 30-39 \text { см } & 10 Y R 2 / 2 \text {, вологий, ущільнений, губч стий, рештки розкл дених болотних }\end{array}$ рослин, корінці рослин, кореневини, червоточини, перехід до горизонту 3 ясний з з б рвленням і ступенем розкл ду торфу; 


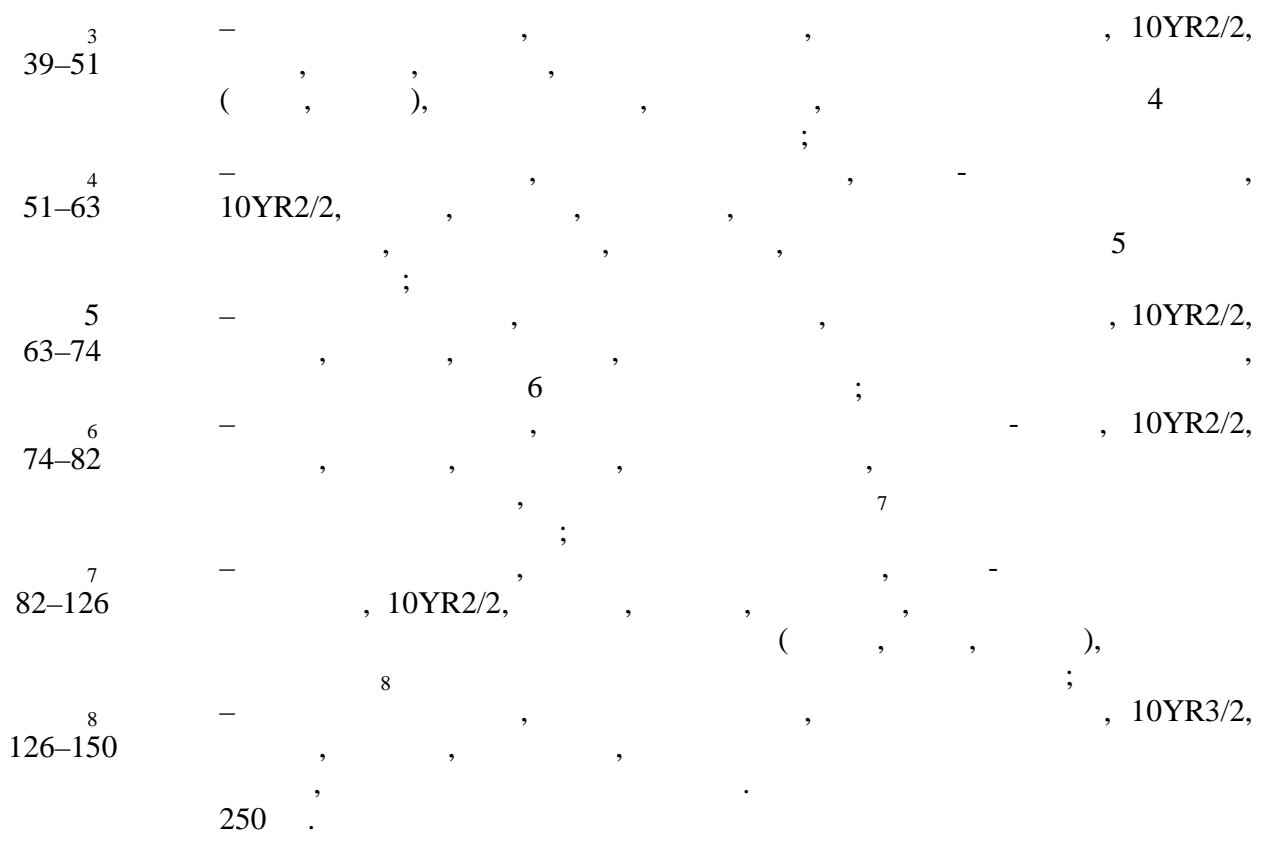

тже, профіль торфових грунтів скл д ється з чітко вир жених орг ногенних горизонтів різного ступеня розкл ду і мінер ліз ції торфу. йвищий ступінь розкл ду, мінер ліз ції і гуміфік ції орг ніки, згідно з н веденими морфологічними опис ми, м ють верхні горизонти торфових грунтів, особливо з умов осушення і використ ння їх під ріллею.

ізном нітність кв льних і суб кв льних умов боліт, х р ктер підстильних порід, водно-мінер льного живлення визн чили особливості бот нічного скл ду, хімічних компонентів орг нічної т мінер льної ч стин торфових грунтів і, відповідно, їхніх фізико-хімічних вл стивостей.

днією з основних фізико-хімічних вл стивостей грунтів є кислотність торфу. кислотно-основними вл стивостями торфові грунти поділяють н нен сичені т н сичені. о нен сичених (кислих) торфових грунтів н леж ть торфи, р водне яких менше 6,0, до н сичених (нейтр льних і к рбон тних) - торфи, р водне яких пон д $6,0[8]$.

ислотно-основні вл стивості торфових грунтів з леж ть від грунтотворних порід, н яких вони утворюються, типу водно-мінер льного живлення, потужності орг ногенних відкл дів, т кож бот нічного скл ду рослинності, 3 якої вони сформув лись. ому зн чення $\mathrm{p}$ торфових грунтів зн чно в рі бельне як у вертик льному (меж х грунтового профілю), т к і в л тер льному н прям х.

орфув то- й торфово-болотні грунти здебільшого м ють лужну ре кцію грунтового розчину. ередні зн чення $\mathrm{p}$ водного в орг ногенній товщі ст новлять 7,3-8,2, p сольового - від 7,0 до 7,5 (див. т блицю). ужність орг ногенної товщі цих грунтів спричинен близькістю з ляг ння к рбон тної грунтотворної породи (елювію мергелів), осушенням т використ нням їх під ріллею. исокі зн чення $\mathrm{p}$ торфув тоболотних грунтів зумовлені з лученням в орний ш р к рбон тної породи. 
ізико-хімічні вл стивості торфових грунтів лого олісся

\begin{tabular}{|c|c|c|c|c|c|}
\hline \multirow{2}{*}{$\begin{array}{r}\text { енетичні } \\
\text { горизонти }\end{array}$} & \multirow{2}{*}{$\begin{array}{c}\text { либин } \\
\text { відбору } \\
\text { зр зків, см } \\
\end{array}$} & \multicolumn{2}{|c|}{$\mathrm{p}$} & \multirow{2}{*}{$\begin{array}{l}\text { міст } \\
\quad 3\end{array}$} & \multirow{2}{*}{ ольність, \% } \\
\hline & & водне & сольове & & \\
\hline \multicolumn{6}{|c|}{ орфув то-болотні к рбон тні грунти (розріз 194) } \\
\hline ТНкор & $0-17$ & $8,2 *$ & 7,5 & 5,2 & 69,9 \\
\hline HPK & $17-23$ & 8,2 & 7,5 & 29,0 & 92,0 \\
\hline Phkgl & $23-42$ & 8,4 & 7,6 & 50,2 & 95,4 \\
\hline $\mathrm{P}(\mathrm{h}) \mathrm{KGl}$ & $42-48$ & 8,2 & 7,6 & 50,8 & 93,4 \\
\hline PKGl & $48-60$ & 8,3 & 7,6 & 39,8 & 93,4 \\
\hline \multicolumn{6}{|c|}{ орфово-болотні к рбон тні грунти (розріз 193) } \\
\hline ThK & $5-28$ & 7,6 & 7,5 & 5,9 & 42,6 \\
\hline $\mathrm{K}$ & $28-39$ & 7,3 & 7,0 & 0,2 & 35,9 \\
\hline PhкGl & $39-45$ & 7,8 & 7,6 & 45,5 & 92,7 \\
\hline $\mathrm{P}(\mathrm{h}) \mathrm{KGl}$ & $45-63$ & 8,0 & 7,7 & 35,7 & 95,7 \\
\hline PKGl & $63-80$ & 8,0 & 7,8 & 65,7 & 95,5 \\
\hline \multicolumn{6}{|c|}{ орфовище низинне неглибоке к рбон тне (розріз 195) } \\
\hline Thкор. & $8-20$ & 7,8 & 7,4 & 3,6 & 36,7 \\
\hline $\mathrm{TK}_{\mathrm{K}}$ & $20-52$ & 7,1 & 7,2 & 0,7 & 23,1 \\
\hline $\mathrm{K}$ & $52-56$ & 7,8 & 7,4 & 23,6 & 91,0 \\
\hline $\begin{array}{ll}\mathrm{P} & \mathrm{Kgl} \\
\end{array}$ & 56-64 & 8,2 & 7,4 & 67,4 & 91,0 \\
\hline PKGl & 64-90 & 8,4 & 7,4 & 68,2 & 93,0 \\
\hline \multicolumn{6}{|c|}{ орфовище низинне середньоглибоке (розріз 198) } \\
\hline${ }_{1}(\mathrm{~h})$ & $3-17$ & 6,7 & 6,3 & - & 30,1 \\
\hline $\mathrm{T}_{2 \mathrm{Fe}}$ & $17-31$ & 6,5 & 6,0 & - & 30,9 \\
\hline $\mathrm{T}_{3}$ & $31-72$ & 5,6 & 5,2 & - & 14,5 \\
\hline $\mathrm{T}_{4}$ & $72-93$ & 4,5 & 4,1 & - & 26,4 \\
\hline $\mathrm{T}_{5}$ & $93-130$ & 5,1 & 4,7 & - & 31,0 \\
\hline $\mathrm{T}_{6}$ & $130-140$ & 2,9 & 2,7 & - & 58,2 \\
\hline \multicolumn{6}{|c|}{ орфовище низинне глибоке (розріз 189) } \\
\hline hd & $0-13$ & 5,8 & 5,3 & - & 42,4 \\
\hline $\mathrm{T}_{1}$ & $13-30$ & 5,8 & 5,4 & - & 40,9 \\
\hline $\mathrm{T}_{2}$ & $30-39$ & 5,7 & 5,5 & - & 18,2 \\
\hline $\mathrm{T}_{3}$ & $39-51$ & 5,8 & 5,5 & - & 10,9 \\
\hline $\mathrm{T}_{4}$ & $51-63$ & 5,9 & 5,8 & - & 12,8 \\
\hline $\mathrm{T}_{5}$ & $63-74$ & 6,4 & 6,2 & - & 10,6 \\
\hline $\mathrm{T}_{6}$ & $74-82$ & 6,5 & 6,2 & - & 11,5 \\
\hline $\mathrm{T}_{7}$ & $82-130$ & 6,5 & 6,1 & - & 10,8 \\
\hline $\mathrm{T}_{8}$ & $130-150$ & 6,4 & 6,2 & - & 11,3 \\
\hline
\end{tabular}

* ількість визн чень $\mathrm{n}=3-5$.

орфовищ низинні лого олісся перев жно н леж ть до н сичених. е кція грунтового розчину в орг ногенній товщі сл бко- і середньолужн, середнє зн чення p водного ст новить 7,1-7,8, p сольового - 7,2-7,4 (див. т блицю). ужн ре кція орг ногенної товщі торфовищ низинних неглибоких зумовлен н явністю н піврозкл дених мушель молюсків, періодичним підтопленням жорсткими грунтовими вод ми через неглибоке з ляг ння мергелів, н дходженням к рбон тних люві льних, 
в ідподільському природному р йоні делюві льних вод, осушенням. ен сичені (кислі) торфовищ низинні тр пляються рідше.

ередньоглибокі й глибокі торфовищ низинні лого олісся 3 кислотноосновними вл стивостями н леж ть до кислих, нейтр льних і к рбон тних. ен сичені торфові грунти приурочені до річкових долин і формуються н безк рбон тних воднольодовикових і д вньо люві льних відкл д х. е кція грунтового розчину в орг ногенній товщі - від сильнокислої до нейтр льної. ередні зн чення $\mathrm{p}$ водного в орг ногенній товщі колив ються від 4,5 до 6,7, p сольового - від 4,1 до 6,3 (див. т блицю).

сто в торфовищ х тр пляються горизонти, н сичені рештк ми мушель молюсків, ре кція розчину в яких лужн . сиви т ких торфовищ зосереджені в долин х річок олокія, т, ричівському потоці т ін. к рбон тних відмін х торфовищ низинних середньоглибоких і глибоких ре кція грунтового розчину колив ється від сл бко- до сильнолужної. н чення р водного ст новить 7,4-8,6, p сольового - 7,0-7,6. прош рк х концентр ції решток мушель молюсків зн чення р водного досяг $€ 10,1$, p сольового - 7,8-8,0 [1]. кі торфовищ поширені в долин х ричівського потоку, річок удилівк, стрівк, кв, в околицях смт лесько.

торфових грунт х лого олісся простежується деяк з кономірність щодо колив ння зн чення $\mathrm{p}$ торфу з лежно від їхньої потужності т ступеня розкл ду орг нічної речовини. прикл д, торфові грунти з незн чним з потужністю торфовим горизонтом, зокрем , торфув то-болотні, торфово-болотні т торфовищ неглибокі, м ють високий ступінь розкл ду орг ніки т високі зн чення р , тобто лужну ре кцію грунтового розчину. середньоглибоких і глибоких торфовищ х низинних ступінь розкл ду орг ніки низький, відповідно, низькі зн чення $\mathrm{p}$ i кисл ре кція грунтового розчину.

ольність торфових грунтів у меж х лого олісся неоднорідн . орфув тоболотні грунти з зольністю 69,9\%, з числено до мулув то-торфових (див. т блицю). орфово-болотні грунти сх р ктеризов но як дуже б г тозольні, зн чення зольності колив ється в меж х 35,9-42,6\%. орфовищ низинні неглибокі, середньоглибокі й глибокі у верхній ч стині профілю - б г тозольні й дуже б г тозольні, зн чення зольності колив ється в меж х 30,1-42,4\%. глибиною зольність суттєво зменшується, торфи перев жно м лозольні, середньозольні т бг тозольні (див. т блицю). ідвищен зольність верхньої ч стини профілю торфових грунтів, розт шов них у річкових долин х, зумовлен періодичним їхнім з мулюв ння п водковими вод ми, т кож прискореною мінер ліз цією орг ніки через осушення і використ ння під ріллею.

енетико-геогр фічні особливості торфових грунтів позн чились н їхньому к рбон тному профілі і вмісті к рбон тів к льцію. явність к рбон тів у торфових грунт х лого олісся н йч стіше зумовлен підстил нням торфів елювієм мергелів бо крейди. орсткі грунтові води, періодично піднім ючись в орг ногенну товщу, н сичують торфи 3 . кі процеси н йч стіше відбув ються в торфув то-болотних, торфово-болотних, менше - торфовищ х низинних неглибоких. ідподільському природному р йоні к рбон тність торфових грунтів зумовлен н дходженням делюві льних к рбон тних вод з прилеглих до ологоро- ременецького горбогір'я схилів, скл дених елювієм щільних к рбон тних порід. рбон тність торфових грунтів лого олісся ч сто м є реліктовий х р ктер і спричинен н явністю решток мушель молюсків. оризонти 3 н піврозкл дених решток мушель тр пляються здебільшого в середньоглибоких, глибоких і н дглибоких торфовищ х. ких горизонтів різної 
потужності у профілі може бути декільк . явність к рбон тних прош рків свідчить про неоднорідність у минулому кв льних умов боліт, у яких сформув лись торфові грунти і торфовищ . явність з в торфових грунт х річкових долин зумовлен відкл денням к рбон тних мулистих люві льних н носів.

результ т ми досліджень, вміст к рбон тів к льцію в орг ногенному профілі торфув то-болотних грунтів ст новить 5,2 \%, торфово-болотних - 0,2-5,94 \%, торфовищ низинних неглибоких - 0,7-23,6 \% (див. т блицю).

сушення торфових грунтів з под льшим їх використ нням під ріллею призвело до зн чних змін водно-повітряного режиму, зміни н пряму грунтотворного процесу. риродні процеси торфоутворення змінились процес ми розкл ду торфу і глибокої тр нсформ ції його орг нічної і мінер льної ч стини [8]. одноч с, осушення торфових грунтів не д ло очікув них результ тів, не було досягнуто з проектов ної врож йності сільськогоспод рських культур, н томість н були м сшт бного х р ктеру дегр д ційні процеси. м сив х торфових грунтів виявлено пересушення, прискорену мінер ліз цію орг ніки, дефляцію, пірогенну дегр д цію.

собливо небезпечним явищем $є$ пірогенн дегр д ція. ожежі н торфовищ $\mathrm{x}$

лого олісся ост нніми десятиріччями тр пляються щороку. лощі горіння торфів, 3 лежно від погодних умов, колив ються від декількох до сотень гект рів і більше. собливо сильні пожежі був ють у долині р. олокії, ричівського потоку. їхню лок ліз цію і г сіння витр ч ють зн чні м тері льно-технічні й людські ресурси. битки, що їх з вд ють пожежі н торфовищ х, для суспільств , і особливо довкілля, оцінити в жко, одн к без сумніву, вони зн чні [1].

ожежі н торфових грунт х є н дзвич йно небезпечним явищем, вони нег тивно вплив ють не лише н грунти, ч стково чи повністю знищуючи їх, й н довкілля 3 г лом. ірогенн дегр д ція призводить до вигор ння торфу, утворення з п динного рельєфу, знищення видового болотного рослинного і тв ринного різном ніття т їхньої чисельності, формув ння н місці природних болотних екосистем і сільськогоспод рських угідь м лоприд тних для використ ння територій. умов м лополіських л ндш фтів, приурочених до флювіогляці льних рівнин, вигор ння торфів спричиняе виходи н денну поверхню мінер льних пісків, сприяе вторинному з болоченню території. собливо небезпечним є утворення вигорілих порожнин у тілі торфової м си, куди пров люється технік, люди, тв рини. ля живих істот і людей пров ли в пірогенні порожнини ч сто 3 кінчуються тр гічно [1, с. 52].

роцеси пірогенної дегр д ції спричинили глибокі деструкції в будові профілю і вл стивостях торфових грунтів. місці вигорілих торфових осушених грунтів формуються специфічні пірогенні утворення - пірогенні дерив ти, які з трудняють використ ння осушених земель. им і попіл від горіння торфовищ нег тивно вплив ють н довкілля, з бруднюючи його [1].

роблем $\mathrm{p}$ ціон льного використ ння й охорони торфових грунтів і торфовищ $€$ кту льною, потребує н укових рішень і держ вної підтримки. ершочергово необхідно провести дет льні грунтові обстеження торфових грунтів і торфовищ, щоб оцінити їхній ст н т інвент ризув ти. реб визн чити, які ділянки торфових грунтів доцільно використовув ти в гр рному секторі, які - під видобуток торфу, н яких м сив х $з$ пров дити консерв цію торфовищ з под льшою рен тур ліз цією у близькі до природних болотні угіддя.

ожежі н торфовищ х і пірогенні утворення створюють певні труднощі сільськогоспод рського використ ння потенційно родючих торфових грунтів. вич йно, 
пірогенну дегр д цію ліпше попередити, ніж боротися з пожеж ми чи ліквідовув ти їхні н слідки. ому необхідн низк профіл ктичних з ходів, які б мінімізув ли з грозу пірогенної дегр д ції торфових грунтів, с ме: використ ння їх під лучними угіддями бо в тр вопільних сівозмін х, двобічне регулюв ння рівня грунтових вод, з стосув ння піщ них культур землеробств , піскув ння торфовищ ш ром піску. орисною буде т кож роз'яснюв льн робот серед н селення щодо екологічних проблем, пов'яз них 3 пірогенною дегр д цією торфових грунтів. жливою л нкою охорони грунтів і довкілля з г лом повинно ст ти з пров дження системи моніторингових спостережень $з$ ст ном осушених торфовищ [1].

тже, торфові грунти і торфовищ 3 йм ють зн чну площу лого олісся, вони $€$ в жливими компонент ми його природних екосистем. еогр фія і генез торфових грунтів вз ємопов'яз н з природними умов ми території. ут сформув лись торфові грунти і торфовищ низинного типу. структурі грунтового покриву утворилися скл дні грунтові комбін ції, перев жно плямистості, т шети, поєдн ння. орфові грунти і торфовищ лого олісся вирізняються зн чною в рі бельністю потужності орг ногенної товщі, фізико-хімічних вл стивостей, ступенем розкл ду і мінер ліз ції орг ніки.

орфові грунти вн слідок осушення і сільськогоспод рського використ ння з зн ли суттєвих змін, ч сто дегр д ційного х р ктеру, тому потребують р ціон льного використ ння й охорони.

1. ськевич . . ірогенн дегр д ція грунтів лого олісся: грунтово-екологічні т соці льно-економічні спекти / . . ськевич, . . ецик // існик ьвів. ун-ту. ер. геогр. - 2008. - ип. 35. - . 49-57.

2. ськевич . . еоретичні основи і прикл дні спекти дегр д ції грунтів лого олісся: дис. ... д-р геогр. н ук: 11.00 .05 / ськевич олодимир еоргійович. ьвів, 2010. - 851 с.

3. емельний кодекс кр їни. - ьвів : “ кр їнські технології, 2001. - 80 с.

4. нишев . . орфяные почвы: их генезис и кл ссифик ция / . . нишев // очвоведение. - 2006. - № 7. - . 781-786.

5. рт грунтів кр їнської - сшт б $1: 200000$ /[гол. ред. проф. . . рупський]. - ., 1968. - ркуші 31-35; 49.

6. озняк . . рунтозн вство і геогр фія грунтів : підручник. 2 ч. .2 / . . . озняк. - ьвів : імені в н р нК, 2010.-286 с.

7. орфяной фонд кр инской /[под ред. . . роворкин , . . ин дского]. - . . : нститут “ ипроторфр зведк”, 1969. - 320 с.

8. руск вецький . . орфові грунти і торфовищ кр їни / . . руск вецький. .: іськдрук, 2010. -278 с.

9. ізичн геогр фія кр їнської / [ . . ринич, . . нько, . . ерб нь, . . ищенко]. - . : ищ школ , 1982.-208 с.

m ття: н дійщл до ред кцї̈ 15.02.2013

доопр иьов н 25.03.2013

прийнят до друку 16.05.2013 


\section{GENETIC-GEOGRAPHICAL FEATURES OF PEAT SOIL OF SMALL POLISSYA}

\section{Volodymyr Gaskevych, aria Netzyk}

Ivan Franko National University of Lviv, P. Doroshenko Str., 41, UA - 79000, Lviv, Ukraine, e-mail: haskevich_vg@ukr.net

The characteristic of the genetic and geographic features of peat soils of Small Polissya was done. The geography of peat soils was outlined on the results of field and laboratory studies. Morphological structure, physical and physical-chemical properties of peat soils were analyzed. The current agroecological status of peat soil and the measures of the rational use and protection were considered.

Key words: peat soils, peat, geography of peat soils, morphological features, drainage, degradation, soil protection.

\section{л димир ськевич, рия ецык}

ввовский н иион льный университет имени в н р нко,

ул. . орошенко, 41, 79000, г. ввов, кр ин,

e-mail: haskevich_vg@ukr.net

риведено х р ктеристику генетико-геогр фических особенностей торфяных почв лого олесья. результ т ми полевых и л бор торных исследов ний очерчено геогр фию торфяных почв, про н лизиров но их морфологическое строение, физические и физико-химические свойств . ссмотрено современное гроэкологическое состояние торфяных почв, мероприятия их р цион льного использов ния и охр ны.

лючевые слов : торфяные почвы, торфяники, геогр фия торфяных почв, морфологические призн ки, осушение, дегр д ция, охр н почв. 